\title{
Biotransformation of hop derived compounds by Brettanomyces yeast strains
}

\author{
Colomer, Marc Serra; Funch, Birgitte; Solodovnikova, Natalia; Hobley, Timothy John; Förster, Jochen
}

Published in:

Journal of the Institute of Brewing

Link to article, DOI:

$10.1002 / j i b .610$

Publication date:

2020

Document Version

Publisher's PDF, also known as Version of record

Link back to DTU Orbit

Citation (APA):

Colomer, M. S., Funch, B., Solodovnikova, N., Hobley, T. J., \& Förster, J. (2020). Biotransformation of hop derived compounds by Brettanomyces yeast strains. Journal of the Institute of Brewing, 126(3), 280-288. https://doi.org/10.1002/jib.610

\section{General rights}

Copyright and moral rights for the publications made accessible in the public portal are retained by the authors and/or other copyright owners and it is a condition of accessing publications that users recognise and abide by the legal requirements associated with these rights.

- Users may download and print one copy of any publication from the public portal for the purpose of private study or research.

- You may not further distribute the material or use it for any profit-making activity or commercial gain

- You may freely distribute the URL identifying the publication in the public portal 


\title{
Biotransformation of hop derived compounds by Brettanomyces yeast strains
}

\author{
Marc Serra Colomer, ${ }^{1,2}$ @ Birgitte Funch, ${ }^{1}$ Natalia Solodovnikova, ${ }^{1}$ \\ Timothy John Hobley ${ }^{2}$ and Jochen Förster ${ }^{1 *}$
}

\begin{abstract}
Several hop derived compounds in wort are known to be converted by yeast during fermentation, influencing the overall perception of the beer. A deeper understanding of such metabolic processes during fermentation is needed to achieve better control of the outcome. Here, the interaction between hop derived compounds and the yeast genera Brettanomyces was studied. Several Brettanomyces strains with different genomic backgrounds were selected, focusing on two traits: beta-glucosidase activity and nitrate assimilation. The role of three beta-glucosidases present in Brettanomyces bruxellensis and Brettanomyces anomalus and their impact on the final monoterpene alcohol profile was analysed. The beta-glucosidase activity was highly strain dependent, with B. anomalus CRL-49 exhibiting the highest conversion. Such activity could not be related to the release of aglycones from hops during fermentation, as a substantial part of such activity was intracellular. Nevertheless, the reduction of geraniol to $\beta$-citronellol was remarkably efficient for all Brettanomyces strains during fermentation, and it is suggested that two oxidoreductases BbHye2 and BbHye 3 may have an influence. Moreover, the transfer of nitrate from hops to wort and its further assimilation by Brettanomyces species was analysed. The amount of nitrate in wort proved to be linearly proportional to the contact time of the hops with the wort. The level of nitrate assimilation by yeast was shown to be dependent on the nitrate assimilation cluster (YNR, YNI, YNT). Hence, the desired yeast strains may be selected according to the genetic make-up. $\odot 2020$ The Authors. Journal of the Institute of Brewing published by John Wiley
\end{abstract} \& Sons Ltd on behalf of The Institute of Brewing \& Distilling

Keywords: Brettanomyces bruxellensis; beta-glucosidase; monoterpene alcohols; nitrate assimilation; beer

\section{Introduction}

The craft brewing boom is driving innovation in the brewing industry, and it places demands on new and alternative practices. Recently, the use of non-conventional yeast species has been explored more rigorously, as the application of the right yeast can strongly influence the flavour profile of a beer. Brettanomyces (anamorph of Dekkera) species have been highlighted for beer flavouring, as their use results in features unachievable with conventional Saccharomyces brewing yeast $(1,2)$. One of these is a positive impact on ester production, leading to fruity flavours. Recently it has been reported that there can be synergistic effects on flavour formation between yeast and hops $(3,4)$. The authors found that monoterpene alcohols from hops can be metabolised by brewer's yeast, imparting tropical and citrus flavours, however the exact mechanisms are not fully understood $(3,5,6)$. It is not clear whether similar effects are catalysed by Brettanomyces species and an evaluation of this would aid in understanding the mechanisms behind the positive attributes of brewing with this yeast.

Bioconversion of hop compounds by conventional and non-conventional yeasts has been described previously (4). During fermentation, the hop derived monoterpene alcohol geraniol which gives a characteristic rose flavour - is reduced by yeast to $\beta$-citronellol (lime flavour), especially in the early stages of fermentation (Fig. 1) $(3,7,8)$. Such a conversion has been correlated with expression of 'old yellow enzyme' (Oye2) by yeast, which is an oxidoreductase responsible for the transformation step $(9,10)$. The citrusy flavour perceived in beers is caused by the synergistic effect of geraniol and citronellol (11). Therefore, an understanding of the interaction of yeast with hop derived compounds is required. De novo synthesis of monoterpene alcohols in conventional brewer's yeast has also been reported, in both natural and genetically engineered strains $(6,12)$.

In addition, beer contains aglycones, sugar molecules bound to monoterpene alcohols that are not volatile and are odourless (13). When the glycosidic bond is broken the aromatic monoterpene alcohols are released and can be perceived by the consumer. Beta-glucosidase activity has been linked to this phenomenon (Fig. 1) $(5,14)$. Several studies have focused on screening beta-glucosidase activity in yeasts, and despite the activity being strongly straindependent, Brettanomyces species display remarkably high activity (15-17). In one of these studies, a $B$. custersianus strain was found with beta-glucosidase activitiy up to ten fold higher than average (15). It has been reported that Brettanomyces can contain two open reading frames (ORFs), which putatively encode for two beta-glucosidases, however the impact of the presence of these genes during brewing has not been explored (18).

\footnotetext{
* Correspondence: Jochen Förster, Carlsberg Research Laboratory, Group Research, Carlsberg A/S, 1799 Copenhagen V, Denmark. Email: jochen. forster@carlsberg.com

1 Carlsberg Research Laboratory, Group Research, Carlsberg A/S, 1799, Copenhagen V, Denmark

2 National Institute for Food, Technical University Denmark, 2800, Kongens Lyngby, Denmark
}

This is an open access article under the terms of the ()Creative Commons Attribution License, which permits use, distribution and reproduction in any medium, provided the original work is properly cited. 


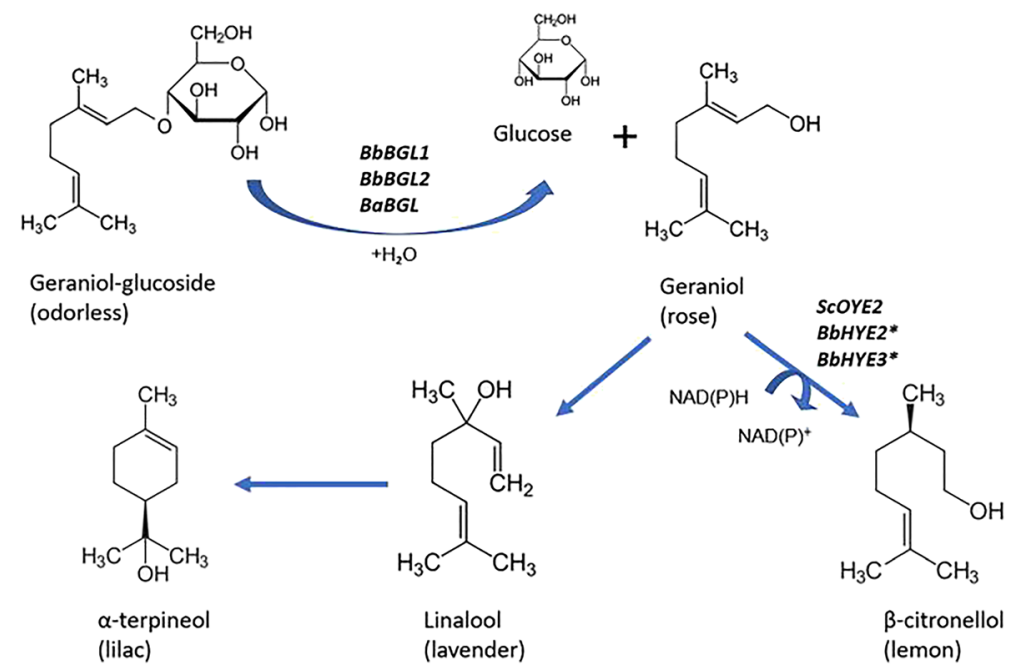

Figure 1. Beta-glucosidase activity on glucosides and bioconversion of monterpene alcohols by yeast. Flavour descriptors adapted from the literature. Genes responsible for the particular reactions are marked in bold. Enzymes marked with $\left(^{*}\right)$ are suggested here but not confirmed. $\mathrm{Bb}=$ Brettanomyces bruxellensis, $\mathrm{Ba}=$ Brettanomyces anomalus, $\mathrm{Sc}=\mathrm{Sac}-$ charomyces cerevisiae. [Colour figure can be viewed at wileyonlinelibrary.com]

Besides the potential for releasing aromatic monoterpene alcohols from hops, Brettanomyces can also affect other hop derived compounds. One compound of particular interest is nitrate. There are restrictions on the maximum concentration of nitrate in foods and water. The allowable maximum residual level (MRL) of nitrate in water and beer in the European Union is $50 \mathrm{mg} / \mathrm{L}$. Typically, the concentration of nitrate in beer is much lower with nitrate transferring from hops during boiling and dry hopping (19). Despite assimilating ammonium, conventional brewing yeast cannot assimilate nitrate and the compound has a negative impact on its fermentation performance (20). In a recent publication, nitrate assimilation by a diversity of yeast species was reported, establishing a phylogenetic association with other metabolic traits, such as the biosynthesis of the molybdenum cofactor (21). In certain occasions, Brettanomyces yeast species have been reported to assimilate nitrate from several substrates (22-24). This requires a nitrate transporter, nitrate and nitrite reductases, encoded by the genes $Y N T, Y N R$ and $Y N I$ respectively (23-25). Nitrate reduction to ammonia is dependent on $\mathrm{NAD}(\mathrm{P}) \mathrm{H}$ (26) (Fig. 2). Furthermore, the metabolism of $B$. bruxellensis has been reported to be influenced by the presence of nitrate in media, leading to expression of genes in the pentose phosphate pathway and TCA cycle $(27,28)$. Of particular relevance to brewing, is that under anaerobic conditions the fermentative capacity of $B$. bruxellensis is improved when nitrate is assimilated, leading to higher ethanol concentration and growth rates (29).

In this study for the first time, we investigated the role of the two beta-glucosidase genes present in Brettanomyces on monoterpene alcohol release, and sought to confirm that this yeast can reduce nitrate levels in beer. A variety of strains were sequenced, the presence or absence of key genes was determined, and relevant strains were then selected. The activity of beta-glucosidase was assayed in selected Brettanomyces strains and the impact on the release of hop derived compounds was examined, during both primary fermentation and secondary fermentation after dry hopping. Finally, worts with different nitrate concentrations were produced and fermented with Brettanomyces strains with selected genetic backgrounds. This allowed the impact of hop dosage on wort nitrate concentration and nitrate assimilation by Brettanomyces strains to be studied.

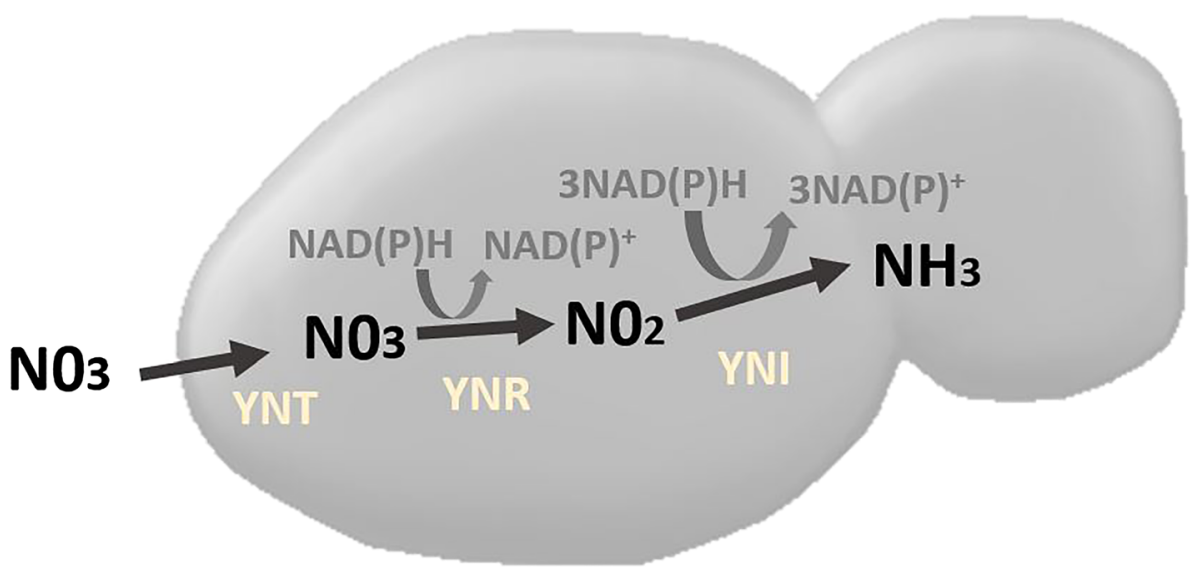

Figure 2. Nitrate assimilation pathway by Brettanomyces species. The enzymes responsible for transportation and conversion to $\mathrm{NH}_{3}$ are indicated in white. Cofactors involved in the reaction are indicated in light grey. [Colour figure can be viewed at wileyonlinelibrary.com] 


\section{Materials and methods}

\section{Microbial strains and media}

Strains of Brettanomyces were obtained from the Carlsberg Research Laboratory's (CRL) collection (CRL-1 to CRL-50 in Table 1). The yeasts were grown on yeast extract $(1 \%, w / v)$ peptone $(2 \%$, $\mathrm{w} / \mathrm{v})$ glucose $(2 \%, \mathrm{w} / \mathrm{v})$ (YPD) media, with agar $(2 \%, \mathrm{w} / \mathrm{v})$ added where required. The strains were grown in $100 \mathrm{~mL}$ Erlenmeyer flasks containing $50 \mathrm{~mL}$ of YPD, under aerobic conditions at $25^{\circ} \mathrm{C}$ with agitation (100 rpm).

\section{DNA sequencing and bioinformatics}

Yeast strains were grown for one week in YPD. Cells were recovered by centrifugation at $4000 \mathrm{~g}$ for 5 minutes at $4^{\circ} \mathrm{C}$, washed in sterile Milli-Q water and recentrifuged. Samples were sent for DNA extraction and whole-genome sequencing, short insert PE150 library, on Illumina HiSeq4000 (BGl-Tech Solutions, Hong Kong). CLC Genomics Workbench software (www. qiagenbioinformatics.com) was used as a tool for bioinformatics analysis. Genome assembly of strains was performed in CLC software using De novo assembly feature. Genes of interest were found in GenBank, accession number (AKS48905.1, EIF45415.1, AKS48904.1) for BbBGL1, BbBGL2 and BaBGL and (EIF45251.1, EIF45249.1, EIF45250.1) for BbYNT, BbYNR and $B b Y N I$, respectively. Nucleotide BLAST tool on CLC software was used to identify the presence or absence of each gene.

\section{Beta-glucosidase assay}

To test beta-glucosidase activity in $B$. bruxellensis and $B$. anomalus, the yeast strains were grown for one week in yeast extract $(1 \%, w / v)$ peptone $(2 \%, w / v)$ cellobiose $(2 \%, w / v)$ (YPC) media. Extracellular, cell associated and intracellular cell fractions were prepared using the modified method of Daenen et al (15). For the extracellular fraction, $1 \mathrm{~mL}$ of culture was transferred to a $1.5 \mathrm{~mL}$ Eppendorf tube (ThermoFisher), centrifuged $(4,000 \mathrm{~g}$, $5 \mathrm{~min}, 4^{\circ} \mathrm{C}$ ) and the supernatant collected. The cultures were adjusted to give an optical density at $600 \mathrm{~nm}$ of 1 . The cells were washed with sterile water and resuspended in phosphate buffered saline (PBS) buffer for the cell associated enzyme fraction. To obtain the intracellular fraction, $0.5 \mathrm{mg} / \mathrm{mL}$ zymolyase (ThermoFisher) was added with PBS and incubated for 1 hour at $37^{\circ} \mathrm{C}$. Glass beads $(425-600 \mu \mathrm{m}$, Sigma) were added to the cell fractions and vortexed twice for 20 seconds and kept on ice. The homogenate was centrifuged (14,000 g, $10 \mathrm{~min}$ ) and the supernatant was collected as the intracellular fraction. The beta-glucosidase activity of each fraction was determined with the MAK129 $\beta$-glucosidase assay kit (Sigma Aldrich). The assay was performed in 96 well plates with $p$-nitrophenyl- $\beta$-Dglucopyranoside ( $\beta-\mathrm{NPG}$ ) as the substrate. The reaction was measured at $405 \mathrm{~nm}$ after a 20 minutes incubation at $37^{\circ} \mathrm{C}$. The results are reported in units/L, where one unit is the amount of enzyme that catalyses the hydrolysis of $1.0 \mu$ mole of substrate per minute at $\mathrm{pH} 7$ and $37^{\circ} \mathrm{C}$.

\section{Fermentation}

To investigate the ability of the Brettanomyces strains to release hop aromas, two experimental approaches were performed: i) An all-malt pale wort, $16^{\circ} \mathrm{P}$ was provided by Jacobsen Breweries for primary fermentation; ii) Jacobsen Indian Pale Ale (IPA) dry hopped beer (Jacobsen Breweries) was used for secondary fermentation, with $1.2 \%(\mathrm{w} / \mathrm{v})$ glucose added to support yeast growth. Fermentations were performed using strains CRL-1, CRL-2, CRL-19, CRL-49 and CRL-50.

To examine the effect of nitrate, standard CRL pilsner wort (Viking malt) with an original gravity of $16^{\circ} \mathrm{P}$ was used. Saaz hops were added at $4 \mathrm{~g} / \mathrm{L}$. Wort $(1.5 \mathrm{~L})$ was transferred to 2 litre glass bottles (Witeg)with the hop pellets contained in a tea bag and the wort was brought to $100^{\circ} \mathrm{C}$ in a water bath. Three different worts were produced, (i) without an additional boil (W1), (ii) with 30 minutes additional boiling (W2) and (iii) with 1 hour additional boiling (W3). Fermentations were performed using strains CRL-1 and CRL-27.

Strains were propagated in the CRL pilsner wort in $50 \mathrm{~mL}$ Erlenmeyer flasks. All fermentations were performed in duplicate in 250 $\mathrm{mL}$ Duran bottles containing $200 \mathrm{~mL}$ of media. The fermentation was allowed to become anaerobic and the ANKOM RF Gas Production System (ANKOM) used to monitor fermentation performance and $\mathrm{CO}_{2}$ release. A pitching rate of $1 \times 10^{5}$ viable cells $/ \mathrm{mL}$ was used (Cellometer X2, Nexelom Bioscience). No samples were taken during fermentation so as to ensure anaerobiosis. Fermentation was complete when no further $\mathrm{CO}_{2}$ release could be measured and the beer was stored at $-20^{\circ} \mathrm{C}$ before analysis.

Table 1. Genomic landscape of Brettanomyces strains used in the study.

\begin{tabular}{|c|c|c|c|c|c|c|c|}
\hline \multirow[b]{2}{*}{ Strain } & \multirow[b]{2}{*}{ Species } & \multicolumn{3}{|c|}{ Beta-glucosidase ORFs } & \multicolumn{3}{|c|}{ Nitrate assimilation genes } \\
\hline & & BbBGL1 & BbBGL2 & $\mathrm{BaBGL}$ & YNR1 & YNI1 & YNT \\
\hline CRL-1 & B. bruxellensis & $X$ & - & - & $X$ & $X$ & $x$ \\
\hline CRL-2 & B. bruxellensis & - & $X$ & - & $X$ & $X$ & $X$ \\
\hline CRL-19 & B. bruxellensis & $x$ & $\mathrm{X}$ & - & $x$ & $x$ & $\mathrm{X}$ \\
\hline CRL-27 & B. bruxellensis & $\mathrm{X}$ & - & - & - & - & - \\
\hline CRL-49 & B. anomalus & - & - & $x$ & $x^{*}$ & $\mathrm{X}^{*}$ & $X^{*}$ \\
\hline CRL-50 & B. bruxellensis & - & - & - & $x$ & $x$ & $x$ \\
\hline
\end{tabular}




\section{Quantification of fermentable sugars, ethanol, monoterpene alcohols and nitrate}

Quantitative analyses of carbohydrates in wort was performed by high-performance anion-exchange chromatography (HPLAEC) using a Dionex ICS-3000 system (Thermo Scientific) with a Dionex PA200 IC column (Thermo Scientific) with a flowrate of $0.5 \mathrm{~mL} / \mathrm{min}$. Eluent gradients were performed with (A) $50 \mathrm{mM}$ $\mathrm{NaOH}$ and (B) $50 \mathrm{mM} \mathrm{NaOH} / 100 \mathrm{mM}$ acetate pressurised with Helium. The column temperature was at $30^{\circ} \mathrm{C}$. Injection volume was kept at $10 \mu \mathrm{L}$ full loop. Samples were filtered through a SEP-PACK C18 (Waters Corporation) and diluted 10x before injection. Reference sugar samples were obtained from Sigma Aldrich and calibration curves were prepared for each measurement.

Ethanol content was quantified with Alcolyser BeerME Analyzing System (www.anton-paar.com). Monoterpene alcohols were quantified using Headspace Gas Chromatography Solid Phase Micro Extraction (HS-GC SPME) following the method described by (30). Nitrate content in wort was determined with HPLC anion exchange column and detected by conductimetry, based on (31). Beer samples were degassed by agitation, filtered through a $0.45 \mu \mathrm{m}$ filter and diluted 10 times with pure water before injection.

\section{Results and discussion}

\section{Genetic characterisation and selection of strains}

Six Brettanomyces strains with different genomic maps were selected to examine the effect of the presence or absence of genes for nitrate assimilation and beta-glucosidase (Table 1). Five of the strains were Brettanomyces bruxellensis and one (CRL-49) Brettanomyces anomalus. For studies of the effect of beta-glucosidase on hop flavour release, CRL-1 and CRL-2 were chosen as they contain just one ORF, BbBGL1 and BbBGL2 respectively. CRL-19 was selected for having both ORFs and CRL-50 for having neither ORF. Furthermore, CRL-1 was chosen as a representative strain possessing all three nitrate assimilation genes, in comparison with strain CRL-27 lacking the nitrate assimilation loci (Table 1).

\section{Genetic background and beta-glucosidase}

Five Brettanomyces strains with different arrangements of the beta-glucosidase genes were assayed for enzyme activity. IntracelIular, cell related and extracellular activities were measured (Fig. 3). The highest activity in the $B$. bruxellensis strains (up to 74 units/L) was detected in the intracellular fraction of CRL-19, which contains both beta-glucosidase ORFs. In contrast, little activity was detected in the strains with only one or no beta-glucosidase encoding genes. The results indicate that $\mathrm{BbBgl} 2$ is more efficient than $\mathrm{BbBgl} 1$ and suggests that there could be an additive effect between the two proteins. Interestingly, Kuo and co-workers purified a heterodimeric structure with beta-glucosidase activity from Dekkera bruxellensis, consisting of two subunits of 50 and $30 \mathrm{kDa}$ (32). Nevertheless, the amino acid sequences of those two subunits do not correlate to the two ORFs found here for the Brettanomyces strains. In contrast to the proteins tested by Kuo (32), our results suggest that such enzymes are primarily located intracellularly, with little secretion (Fig. 3), similar to the findings of Blondin et al (33).

The intracellular fraction of $B$. anomalus CRL-49 showed the highest activity among all the Brettanomyces strains tested (144 units/L). The potential of $B$. anomalus beta-glucosidase activity over $B$. bruxellensis has been reported before (16). Interestingly, beta-glucosidase activity was also detected in the cellular fraction of CRL-49, suggesting that the enzyme could be associated with the cell wall in Brettanomyces anomalus.

\section{Hop aroma conversion by Brettanomyces strains during pri- mary fermentation}

Brettanomyces strains producing different beta-glucosidase enzymes were selected to examine whether they could facilitate the release of hop flavour compounds. The effects on primary fermentation (before dry hopping) were examined first, as the Brettanomyces strains would be anticipated to have high viability with little release of the intracellular beta-glucosidase. Fermentations proceeded for 10 days, by which time $\mathrm{CO}_{2}$ release had stopped. The fermentations for all strains were similar, as shown by $\mathrm{CO}_{2}$ production (Fig. 4A) and ethanol formation (7.5 $\pm 0.2 \%$; Table 2). However, B. bruxellensis CRL-2 was an exception as it

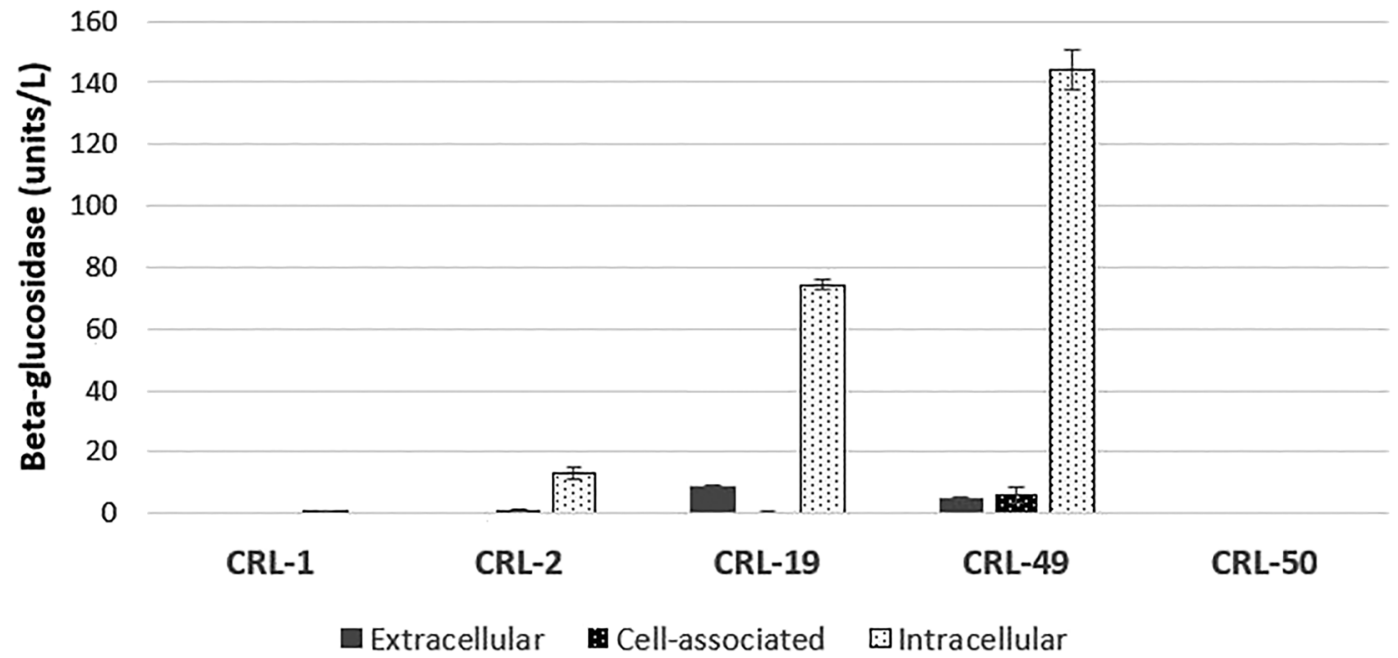

Figure 3. Activity of beta-glucosidase in the different cell fractions of Brettanomyces strains. Values are the average of two replicates and error bars show the standard deviation. The results are given in units $/ \mathrm{L}$, where one unit is the amount of enzyme that catalyses the hydrolysis of $1.0 \mu$ mole of substrate per minute at $\mathrm{pH} 7$ and $37^{\circ} \mathrm{C}$. 
A

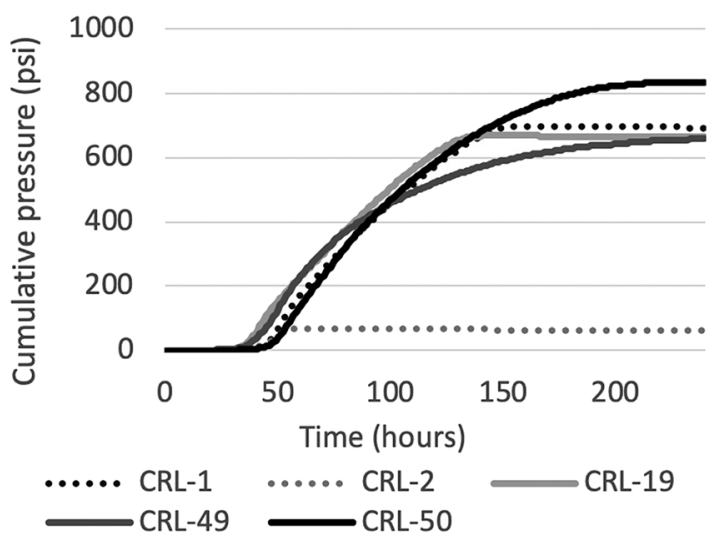

B

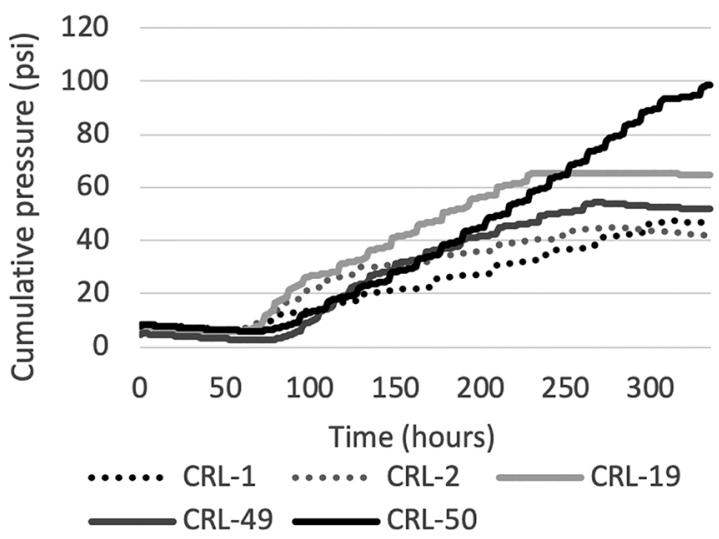

Figure 4. Cumulative pressure measured in primary (A) and secondary (B) fermentation. Strains were fermented in duplicate, and the curve represents the average values.

Table 2. Ethanol and fermentable sugars after primary fermentation and secondary fermentation (shaded). Standard deviation is reported $(n=2)$.

\begin{tabular}{|cccccc|} 
& Ethanol $(\%, \mathrm{v} / \mathrm{v})$ & Glucose $(\mathrm{mg} / \mathrm{L})$ & Maltose $(\mathrm{mg} / \mathrm{L})$ & Maltotriose $(\mathrm{mg} / \mathrm{L})$ & Maltotetraose $(\mathrm{mg} / \mathrm{L})$ \\
\hline CRL-1 & $7.49 \pm 0.13$ & $4 \pm 2$ & $0 \pm 0$ & $179 \pm 19$ & $3225 \pm 150$ \\
CRL-2 & $1.71 \pm 0.02$ & $91 \pm 16$ & $60215 \pm 3559$ & $16674 \pm 839$ & $3325 \pm 157$ \\
CRL-19 & $7.39 \pm 0.08$ & $10 \pm 14$ & $22 \pm 30$ & $67 \pm 46$ & $2686 \pm 1072$ \\
CRL-49 & $7.3 \pm 0.05$ & $0 \pm 0$ & $15 \pm 21$ & $3403 \pm 388$ & $3064 \pm 148$ \\
CRL-50 & $7.75 \pm 0.32$ & $97 \pm 4$ & $1570 \pm 549$ & $19 \pm 7$ & $81 \pm 1$ \\
CRL-1 & $6.97 \pm 0.0$ & $9 \pm 1$ & $553 \pm 100$ & $9012 \pm 721$ & $1414 \pm 48$ \\
CRL-2 & $6.82 \pm 0.17$ & $12 \pm 4$ & $827 \pm 332$ & $9711 \pm 1883$ & $1396 \pm 70$ \\
CRL-19 & $6.91 \pm 0.04$ & $10 \pm 8$ & $842 \pm 264$ & $12396 \pm 4254$ & $1377 \pm 0$ \\
CRL-49 & $6.96 \pm 0.06$ & $9 \pm 3$ & $407 \pm 137$ & $8518 \pm 373$ & $1260 \pm 14$ \\
CRL-50 & $7.32 \pm 0.39$ & $16 \pm 5$ & $785 \pm 17$ & $3202 \pm 1874$ & $916 \pm 140$ \\
\hline
\end{tabular}

was not able to metabolise maltose. Ethanol production by CRL-50 was the highest due to its ability to ferment dextrins, as shown by utilisation of maltotetraose (Table 2). At the end of fermentation samples were analysed for monoterpene alcohols and compared to the wort. The results in Fig. 5A show that yeast strains CRL-1 (one ORF) and CRL-50 (no ORFs), which had the lowest beta-glucosidase activities led to the greatest concentrations of $\beta$-citronellol, reaching levels up to $31.5 \mu \mathrm{g} / \mathrm{L}$ after fermentation for CRL-50. Furthermore, CRL-2 (lacking one ORF and maltose utilisation) had the lowest conversion of geraniol to $\beta$-citronellol. The same pattern was seen in all the strains; the content of geraniol decreased in favour of the production of $\beta$-citronellol. Linalool was converted to $\alpha$-terpineol but at lower rate. Following conventional pathways, myrcene was completely depleted in all cases and isoamyl isobutyrate was slightly increased (34). No correlation between beta-glucosidase activity (Fig. 4) and aroma released from aglycones (Fig. 5) was seen. To our knowledge, such large amounts of $\beta$-citronellol are rarely reported without the use of dry-hopping. In Saccharomyces yeast, $\beta$-citronellol formation has been strongly correlated with Oye2 activity (9). In the Brettanomyces genome sequences reported here, two proteins were identified as potential homologs of Oye 2 and Oye3, showing domains of flavin mononucleotide (FMN) oxidoreductase activity. A BLAST search revealed a $58 \%$ similarity with 'hansenula yellow enzyme' 2 and 3 of Hansenula polymorpha. Accordingly, the proteins are referred to as BbHye2 and BbHye3 (35). Accordingly, the results reported here suggest that oxidoreductases $\mathrm{BbHye} 2$ and $\mathrm{BbHye} 3$ cause stronger monoterpene alcohol conversion than the conventional brewer's yeast ScOye2. This could contribute a more stable redox metabolism under anaerobiosis in Brettanomyces by the regeneration of $\mathrm{NAD}^{+}$(Fig. 1).

\section{Hop aroma conversion by Brettanomyces strains during sec- ondary fermentation}

A dry hopped commercial beer supplemented with glucose (1.2\%, $\mathrm{w} / \mathrm{v}$ ) was inoculated with the respective strain of Brettanomyces, re-sealed in the ANKOM system and refermented for 14 days. At this point, the glucose had been consumed as shown by the $\mathrm{CO}_{2}$ accumulation curves (Fig. 4B) and between 6.8 and 7.3\% (v/v) alcohol had been produced (Table 3 ). The total amount of monoterpene alcohols were higher in the secondary fermentations compared to the primary fermentations due to dry hopping (Fig. 5B). However, bioconversion of monoterpene alcohols occurred to a similar extent as in the primary fermentationwith, in both cases, the conversion of ca. $25 \mu \mathrm{g} / \mathrm{L}$ geraniol. As in the primary fermentations, Brettanomyces strains increased $\alpha$-terpineol and $\beta$-citronellol content while reducing linalool and geraniol. There was no correlation between strain dependent beta-glucosidase activity (Fig. 4) and hop aromas, suggesting that the intracellular beta-glucosidase was 


\section{A Primary fermentation}

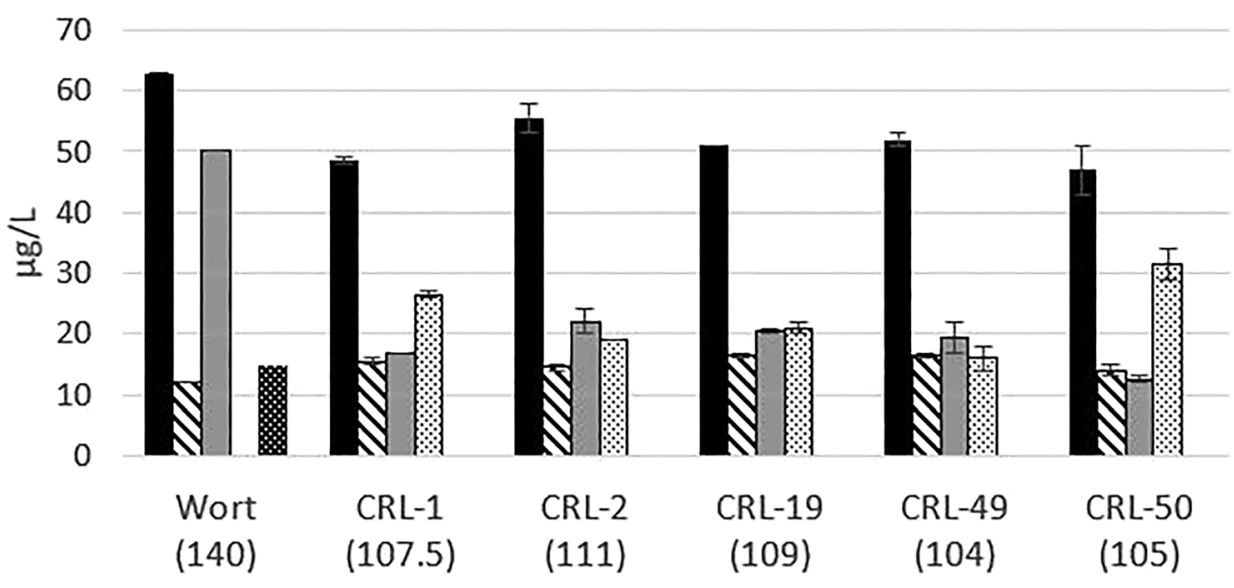

Linalool $\mathbf{\Delta} \alpha$-Terpineol $\square$ Geraniol $\quad$ $\beta$-Citronellol Myrcene

B

Secondary fermentation

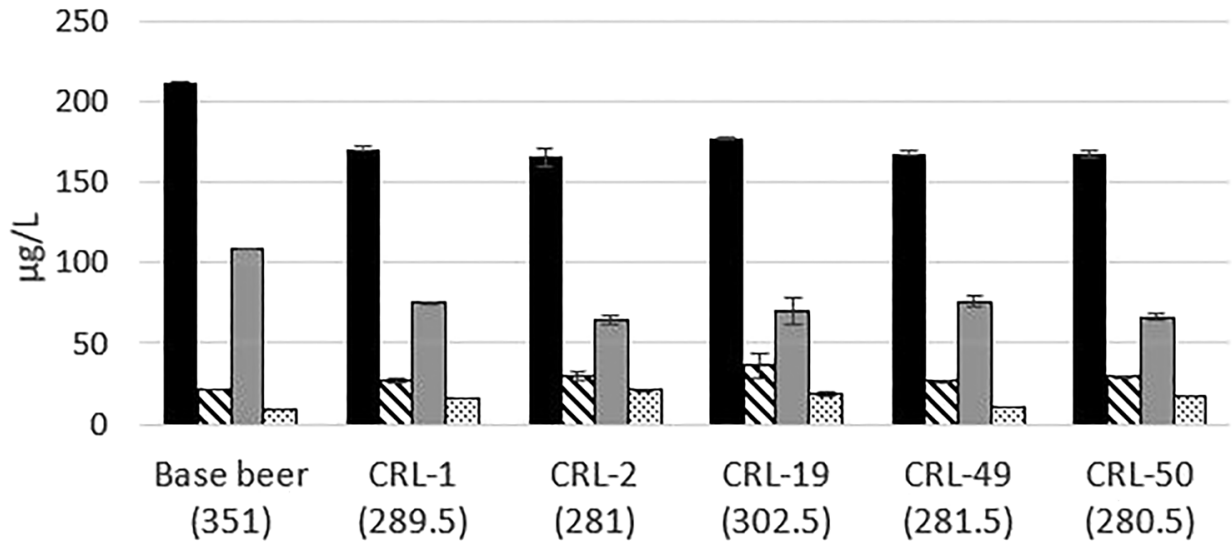

- Linalool $\boldsymbol{\nabla} \alpha$-Terpineol $\square$ Geraniol $\beta \beta$-Citronellol

Figure 5. Monoterpene alcohols in beers after fermentation with Brettanomyces as primary (A) or secondary (B) yeasts. The sum of monoterpene alcohols by strain is indicated in ug/L. Standard deviation is shown by error bars $(n=2)$.

Table 3. Ethanol production after fermentation of Pilsner wort with varying nitrate content.

\begin{tabular}{|lcccc|} 
Yeast & Media & Hop contact time $(\mathrm{min})$ & Initial nitrate content (mg/L) & Alcohol (\%, v/v) \\
\hline CRL-1 & Pilsner Wort 1 & 0 & 1.8 & $7.04 \pm 0.12$ \\
CRL-1 & Pilsner Wort 2 & 30 & 11.7 & $7.02 \pm 0.06$ \\
CRL-1 & Pilsner Wort 3 & 60 & 22 & $6.89 \pm 0.21$ \\
CRL-27 & Pilsner Wort 1 & 0 & 1.8 & $7.2 \pm 0.0$ \\
CRL-27 & Pilsner Wort 2 & 30 & 11.7 & $7.1 \pm 0.04$ \\
CRL-27 & Pilsner Wort 3 & 60 & 22 & $6.96 \pm 0.08$ \\
\hline
\end{tabular}

not available to release of aglycones from hops. In support of this, Takoi et al 2010 (3) reported the release of glycosidically bound precursors using added Sumizyme BGA, a commercial beta-glucosidase derived from Aspergillus niger (3). Nevertheless, a treatment at $50^{\circ} \mathrm{C}$ for 60 min was included, which is unsuitable for beer. Other studies have reported optimal activity at even higher temperatures (16). Other enzymes such as an extracellular exoglucanase protein encoded by EXG1 gene have been related 
to non-specific activity of sugar bound molecules $(17,32,36,37)$ Further research is needed to evaluate the specific role of proteins in the release of hop aglycones and the bioflavouring of beerand whether other compounds such as nerol or ergosterol derivatives contribute to the bioconversion.

\section{Effect of hop boiling time on the nitrate content in wort}

The transfer of nitrate from hops to wort was investigated by varying wort boiling time with $0,0.5$ and 1 hour of additional boiling. The concentration of nitrate in the worts was respectively 1.8, 11.7 and $22 \mathrm{mg} / \mathrm{L}$ This linear $\left(R^{2}=0.9999\right)$ increase in nitrate over time is in agreement with previous studies (19). The nitrate levels were below the maximum residual level in the EU (50 mg/L). However, this will be dependent on the hop variety and treatment during cultivation (38). These results confirm that hops are a significant source of nitrate in wort and confirm the risk that long contact times or large hop additions can result in the release of high concentrations of nitrate.

\section{Effect of fermentation by Brettanomyces strains on nitrate concentration}

Fermentations were conducted in wort containing different concentrations of nitrate with two strains of Brettanomyces. Strain CRL-1 contained all the nitrate assimilation genes whereas CRL-27 had none of these genes. Nitrate and ethanol concentrations were measured in final beers, harvested after 9 days of fermentation when $\mathrm{CO}_{2}$ production had stopped (Fig. 6). The results in Fig. 7 show that the nitrate concentration was unaffected in the fermentation with CRL-27 (without the nitrate assimilation cluster). In contrast, nitrate was almost fully consumed in

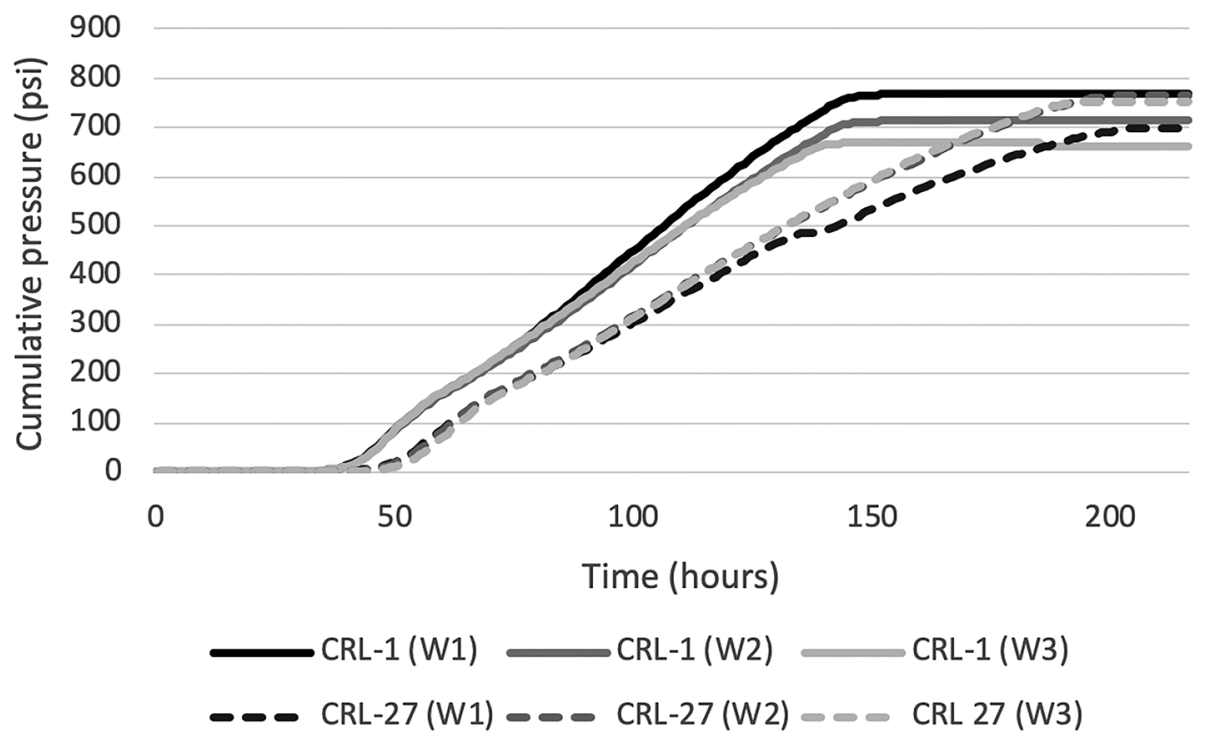

Figure 6. Fermentation of worts with varying nitrate content with Brettanomyces CRL-1 (+ nitrate assimilation) and CRL-27 (- nitrate assimilation). Curves represent the average values of duplicate fermentations. Wort 1 (W1) had no additional boiling, Wort 2 (W2) had additional hop boiling for 30 minutes, Wort 3 (W3) was boiled for 1 hour

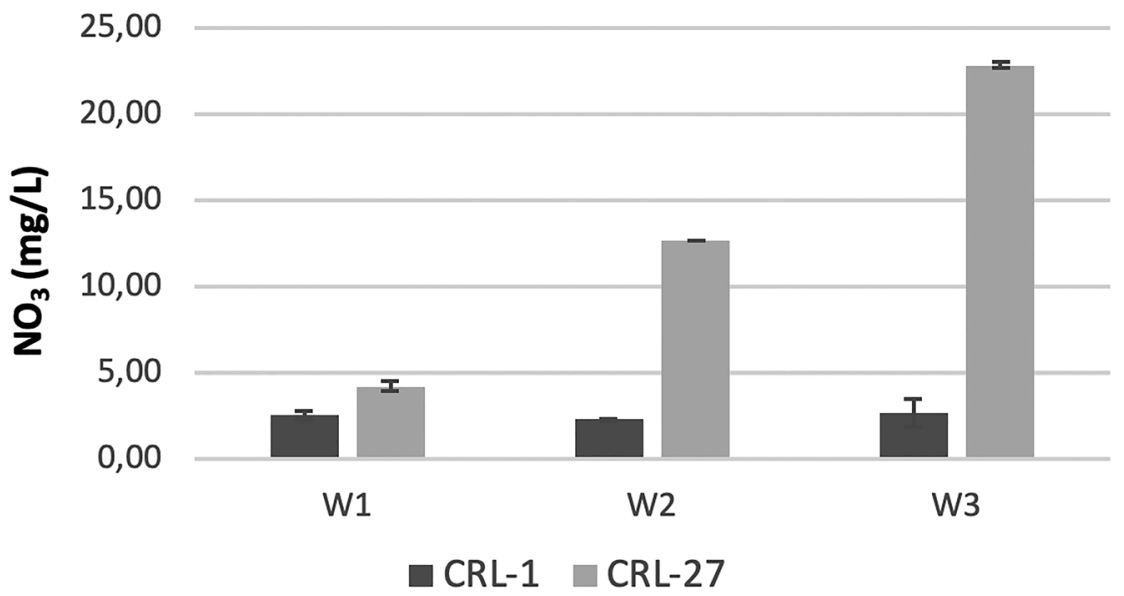

Figure 7. Nitrate content after fermentation with different $B$. bruxellensis strains in worts $\mathrm{W} 1, \mathrm{~W} 2, \mathrm{~W} 3$ containing $1.8,11.7$ and $22 \mathrm{mg} / \mathrm{ml} \mathrm{NO} \mathrm{O}_{3}$ respectively. Wort 1 (W1) had no additional boiling, Wort 2 (W2) had additional hop boiling for 30 minutes, Wort 3 (W3) was boiled for 1 hour . CRL-1 contains the nitrate assimilation loci, CRL-27 does not. 
fermentations with CRL-1, which contained all of the nitrate assimilation genes. Interestingly, ca. $2.5 \mathrm{mg} / \mathrm{mL}$ nitrate remained in the CRL-1 fermentations, independent of the starting concentration, suggesting that the capacity of the Brettanomyces strain for nitrate reduction is much higher. Furthermore, despite nitrite $\left(\mathrm{NO}_{2}\right)$ being the an intermediate in the pathway, it was not detected in any sample. This suggests that the enzyme nitrite reductase is efficient in reducing nitrite to ammonia $\left(\mathrm{NH}_{3}\right)$.

Despite wort being rich in amino acids and the preferred nitrogen source in Brettanomyces (39), nitrate was efficiently assimilated during fermentation. This has been linked to the need of yeast to reoxidise $\mathrm{NAD}(\mathrm{P}) \mathrm{H}$, to maintain the redox balance and enable cell growth (28). Examination of the fermentation data suggests that the fermentative metabolism was not affected by the assimilation of nitrate, in contrast to previous studies $(28,29,40)$. This is presumably due to the content of nitrate in wort which was much lower than previously reported ( $>240 \mathrm{mg} / \mathrm{L}$ ) (40), suggesting that the nitrate level transferred by hops was not significant enough to make an impact on yeast metabolism.

\section{Conclusions}

In this study, the interaction between hop derived compounds and yeast of the genus Brettanomyces was studied. In particular, beta-glucosidase activity was found to be highly strain dependent, with Brettanomyces anomalus the most efficient in converting $\beta$ substrates. The beta-glucosidase activity of Brettanomyces strains is almost exclusively intracellular and therefore has little impact on the release of hop derived monoterpene alcohols during fermentation. In addition, the conversion of geraniol into $\beta$-citronellol was substantially higher, most likely from a direct contribution of the oxidoreductase proteins $\mathrm{BbHye} 2$ and BbHye3. Furthermore, it was demonstrated that nitrate levels in wort increased linearly with time during wort boiling, but the level was reduced during subsequent Brettanomyces fermentation. No effect on nitrate levels was seen in a strain lacking the nitrate assimilation genes, confirming that YNR1, YNI1 and YNT are required for nitrate metabolism.

\section{Author contributions}

MSC designed, performed the experiments and wrote the manuscript, BF provided technical support, NS supported the experimental design, TJH supported writing the manuscript, JF supported the experimental design and overall supervision.

\section{Acknowledgements}

The authors would like to acknowledge Dr Rosa Garcia Sanchez for critical review of the manuscript, Dr Ross Fennessy for experimental discussion, Dr Anna Chailyan for bioinformatics support, the Brewing Science Department at CRL, Jacobsen Breweries for providing wort and beer and the Carlsberg Group Development for Analytics support. The project was supported by Innovationsfonden Denmark. MSC is a recipient of an Industrial PhD fellowship (project 5189-00057).

\section{Conflict of interest}

A patent application protecting some of this work has been submitted by Carlsberg Breweries.

\section{References}

1. Schifferdecker AJ, Dashko S, Ishchuk OP, Piškur J. 2014. The wine and beer yeast Dekkera bruxellensis. Yeast 31:323-332. https://doi.org/ 10.1002/yea.3023.

2. Serra Colomer M, Funch B, Forster J. 2019. The raise of Brettanomyces yeast species for beer production. Curr Opin Biotechnol 56:30-35. https://doi.org/10.1016/j.copbio.2018.07.009.

3. Takoi K, Koie K, Itoga $Y$, Katayama $Y$, Shimase M, Nakayama $Y$, Watari J. 2010. Biotransformation of hop derived monoterpene alcohols by lager yeast and their contribution to the flavor of hopped beer. J Agric Food Chem 58:5050-5058. https://doi.org/ $10.1021 / \mathrm{jf} 1000524$.

4. King A, Dickinson JR. 2000. Biotransformation of monoterpene alcohols by Saccharomyces cerevisiae, Torulaspora delbrueckii and Kluyveromyces lactis. Yeast 16:499-506. https://doi.org/10.1002/(SICl) 1097-0061 (200004) 16:6<499::AID-YEA548>3.0.CO;2-E.

5. Haslbeck K, Jerebic S, Zarnkow M. 2017. Characterization of the unfertilized and fertilized hop varieties progress and hallertauer tradition. Analysis of free and glycosidic-bound flavor compounds and $\beta$ glucosidase activity. Brew Sci 70:148-158. https://doi.org/10.23763/ BrSc17-15haslbeck.

6. Haslbeck K, Bub S, von Kamp K, Michel M, Zarnkow M, Hutzler M, Coelhan M. 2018. The influence of brewing yeast strains on monoterpene alcohols and esters contributing to the citrus flavour of beer. J Inst Brew 124:403-415. https://doi.org/10.1002/jib.523.

7. Takoi K, Itoga Y, Koie K, Takayanagi J, Kaneko T, Watanabe T, Matsumto I, Nomura M. 2017. Systematic analysis of behaviour of hop-derived monoterpene alcohols during fermentation and new classification of geraniol-rich flavour hops. Brew Sci 70:177-186. https://doi.org/ 10.23763/BrSc17-17takoi.

8. King AJ, Dickinson JR. 2003. Biotransformation of hop aroma terpenoids by ale and lager yeasts. FEMS Yeast Res 3:53-62. https://doi.org/ 10.1016/S1567-1356(02)00141-1.

9. Yuan T-T, Chen Q-Q, Zhao P-J, Zeng Y, Liu X-Z, Lu S. Identification of enzymes responsible for the reduction of geraniol to citronellol. Nat Products Bioprospect 1:108-111. https://doi.org/10.1007/s13659-0110032-6.

10. Steyer D, Erny C, Claudel P, Riveill G, Karst F, Legras JL. 2013. Genetic analysis of geraniol metabolism during fermentation. Food Microbiol 33:228-234. https://doi.org/10.1016/j.fm.2012.09.021.

11. Takoi K, Itoga $Y$, Koie K, Kosugi T, Shimase M, Katayama Y, Nakayama $Y$, Watari J. 2010. The contribution of geraniol metabolism to the citrus flavour of beer: Synergy of geraniol and $\beta$-citronellol under coexistence with excess linalool. J Inst Brew 116:251-260. https://doi.org/10.1002/ j.2050-0416.2010.tb00428.x.

12. Denby CM, Li RA, Vu VT, Costello Z, Lin W, Chan UG, Williams J, Donaldson B, Bamforth CW, Petzold CJ, Scheller HV, Martin HG, Keasling JD. 2018. Industrial brewing yeast engineered for the production of primary flavor determinants in hopped beer. Nat Commun 9:965 https://doi.org/10.1038/s41467-018-03293-x.

13. Kollmannsberger $\mathrm{H}$, Biendl M, Nitz S. 2006. Occurence of glycosidically bound flavour compounds in hops, hop products and beer. Monatsschrift Fur Brauwiss 5:83-89.

14. Daenen L, Vanderhaegen B, Verachtert H, Derdelinckx G. 2004. Flavour enhancement in beer by yeast beta-glucosidase activity. Commun Agric Appl Biol Sci 69:73-76.

15. Daenen L, Saison D, Sterckx F, Delvaux FR, Verachtert H, Derdelinckx G. 2008. Screening and evaluation of the glucoside hydrolase activity in Saccharomyces and Brettanomyces brewing yeasts. J Appl Microbiol 104:478-88. https://doi.org/10.1111/j.1365-2672.2007.03566.x.

16. Vervoort $Y$, Herrera-Malaver B, Mertens S, Guadalupe Medina V, Duitama J, Michiels L, Dederlinckx G, Voordeckers K, Verstrepen KJ. 2016. Characterization of the recombinant Brettanomyces anomalus $\beta$-glucosidase and its potential for bioflavouring. J Appl Microbiol 121:721-733. https://doi.org/10.1111/jam.13200.

17. Daenen L, Sterckx F, Delvaux FR, Verachtert H, Derdelinckx G. 2008. Evaluation of the glycoside hydrolase activity of a Brettanomyces strain on glycosides from sour cherry (Prunus cerasus L.) used in the production of special fruit beers. FEMS Yeast Res 8:1103-1114. https://doi.org/ 10.1111/j.1567-1364.2008.00421.x.

18. Crauwels S, Steensels J, Aerts G, Willems KA, Verstrepen KJ, Lievens B. 2015. Brettanomyces bruxellensis, essential contributor in spontaneous beer fermentations providing novel opportunities for the brewing industry. Brew Sci 68:110-121. 
19. Kippenberger M, Hanke S, Biendl M, Stettner G, Lagemann A. 2014 Transfer of nitrate and various pesticides into beer during dry hopping. Brew Sci 67:1-9. https://doi.org/10.1002/job.236.

20. Kurtzman CP, Fell JW, Boekhout T. 2011. The Yeasts: A Taxonomic Study, 5th Edition. vol. 1-3. https://doi.org/10.1017/CBO9781107415324.004.

21. Shen X-X, Opulente DA, Kominek J, Zhou X, Steenwyk JL, Buh KV, Haase MA, Wisecaver JH, Wang M, Doering DT, Boudouris JT, Schneider RM, Langdon QK, Ohkuma M, Endoh R, Takashima M, Manabe RI, Čadež N, Libkind D, Rosa CA, DeVirgilio J, Hulfachor AB, Groenewald M, Kurtzman CP, Hittinger CT, Rokas A. 2018. Tempo and Mode of Genome Evolution in the Budding Yeast Subphylum. Cell 175:1533-1545. https://doi.org/10.1016/j.cell.2018.10.023.

22. van der Walt JP. 1963. Nitrite utilization by Brettanomyces. Antonie Van Leeuwenhoek 29:52-56. https://doi.org/10.1007/BF02046038.

23. Borneman AR, Zeppel R, Chambers PJ, Curtin CD. 2014. Insights into the Dekkera bruxellensis genomic landscape: comparative genomics reveals variations in ploidy and nutrient utilisation potential amongst wine isolates. PLoS Genet 10(2): e1004161 https://doi.org/10.1371/journal.pgen. 1004161

24. Woolfit M, Rozpdowska E, Piškur J, Wolfe KH. 2007. Genome survey sequencing of the wine spoilage yeast Dekkera (Brettanomyces) bruxellensis. Eukaryot Cell 6:721-733. https://doi.org/10.1128/ EC.00338-06.

25. Pérez MD, González C, Avila J, Brito N, Siverio JM. 1997. The YNT1 gene encoding the nitrate transporter in the yeast Hansenula polymorpha is clustered with genes YNI1 and YNR1 encoding nitrite reductase and nitrate reductase, and its disruption causes inability to grow in nitrate. Biochem J 321:397-403. https://doi.org/10.1042/bj3210397.

26. Siverio JM. Assimilation of nitrate by yeasts. 2002. FEMS Microbiol Rev 26:277-84. https://doi.org/10.1016/S0168-6445(02)00100-6.

27. De Barros Pita W, Tiukova I, Leite FCB, Passoth V, Simões DA, De Morais MA. 2013. The influence of nitrate on the physiology of the yeast Dekkera bruxellensis grown under oxygen limitation. Yeast 30:111-117. https://doi.org/10.1002/yea.2945.

28. De Barros Pita W, Leite FCB, De Souza Liberal AT, Simões DA, De Morais MA. 2011. The ability to use nitrate confers advantage to Dekkera bruxellensis over S. cerevisiae and can explain its adaptation to industrial fermentation processes. Antonie van Leeuwenhoek 100:99-107. https:// doi.org/10.1007/s10482-011-9568-z.

29. Galafassi S, Capusoni C, Moktaduzzaman M, Compagno C. 2013. Utilization of nitrate abolishes the "custers effect" in Dekkera bruxellensis and determines a different pattern of fermentation products. J Ind Microbio Biotechnol 40:297-303. https://doi.org/10.1007/s10295-012-1229-3.

30. Praet T, Van Opstaele F, De Causmaecker B, Bellaio G, De Rouck G, Aerts G, De Couman L. 2015. De novo formation of sesquiterpene oxidation products during wort boiling and impact of the kettle hopping regime on sensory characteristics of pilot-scale lager beers. Brew Sci 68:130-145.

31. Bom L. 2010. Mise en place d'une méthode d'analyse des anions par chromatographie liquide haute performance colonne échangeuse d'ions et détecteur conductimétrique. Rapport de stage de licence professionnelle Industries Chimiques et Pharmaceutiques

32. Kuo HP, Wang R, Huang CY, Lai JT, Lo YC, Huang ST. 2018. Characterization of an extracellular $\beta$-glucosidase from Dekkera bruxellensis for resveratrol production. J Food Drug Anal 26:163-171. https://doi.org/ 10.1016/j.jda.2016.12.016.

33. Blondin B, Ratomahenina R, Arnaud A, Galzy P. 1983. Purification and properties of the $\beta$-glucosidase of a yeast capable of fermenting cellobiose to ethanol: Dekkera intermedia van der walt. Eur J Appl Microbiol Biotechnol 17:1-6. https://doi.org/10.1007/BF00510563.

34. Haslbeck K, Bub S, Schönberger C, Zarnkow M, Jacob F, Coelhan M. 2017. On the fate of $\beta$-myrcene during fermentation-the role of stripping and uptake of hop oil components by brewer's yeast in dry-hopped wort and beer. Brew Sci 70:159-169. https://doi.org/ 10.23763/BrSc17-16haslbeck.

35. Komduur JA, Leão AN, Monastyrska I, Veenhuis M, Kiel JAKW. 2002. Old yellow enzymes confers resistance of Hansenula polymorpha towards allyl alcohol. Curr Genet 41:401-406. https://doi.org/10.1007/s00294002-0321-z.

36. Schmidt S, Rainieri S, Witte S, Matern U, Martens S. 2011. Identification of a Saccharomyces cerevisiae glucosidase that hydrolyzes flavonoid glucosides. Appl Environ Microbiol 77:1751-1757. https://doi.org/ 10.1128/AEM.01125-10.

37. Holt S, Miks MH, De Carvalho BT, Foulquié-Moreno MR, Thevelein JM. 2019. The molecular biology of fruity and floral aromas in beer and other alcoholic beverages. FEMS Microbiol Rev 43:193-222. https://doi. org/10.1093/femsre/fuy041.

38. Brown JR, Smith GE. 1966. Soil fertilization and nitrate accumulation in vegetables. Agron J 58:209-212.

39. Parente DC, Cajueiro DBB, Moreno ICP, Leite FCB, De Barros Pita W, De Morais MA. 2018. On the catabolism of amino acids in the yeast Dekkera bruxellensis and the implications for industrial fermentation processes. Yeast 35:299-309. https://doi.org/10.1002/yea.3290.

40. Peña-Moreno IC, Castro Parente D, da Silva JM, Andrade Mendonça A Rojas LAV, de Morais Junior MA, De Barros Pita W. 2018. Nitrate boosts anaerobic ethanol production in an acetate-dependent manner in the yeast Dekkera bruxellensis. J Ind Microbiol Biotechnol 46:209-220. https:// doi.org/10.1007/s10295-018-2118-1. 